\title{
Opportunities and Challenges of Labor Law Construction under the Background of Supply-side Reform
}

\author{
Yu Zhijie ${ }^{1}$ \\ ${ }^{1}$ Weifang Municipal Party School of the CPC Weifang 262406, Shandong, China
}

\begin{abstract}
In the context of global economic integration, the driving force to promote social development has shifted quietly. In the era of knowledge economy, the emergence of cloud computing and intelligence industries has solved the problems of high costs of IT in the past, strengthened artificial intelligence and big data applications, enhanced the efficiency of the use of resources in the entire process of the industry, and promoted industrial integration and upgrading. In the construction of the labor rule of law, the current background of our country needs to be taken into account and intellectual technologies such as cloud computing can be applied to improve the "Labor Contract Law" and maintain harmonious and stable labor relations. The role of human resources should be given full play in the social development process to solve the current problems such as the lack of flexibility in labor relations, the deviation of the public's perception of labor law, and the imbalance of legal regulation, so as to accelerate our economic development.
\end{abstract}

\section{Introduction}

In order to advance the journey of modernization, our country formulates a supply-side reform strategy, hoping to adjust the industrial structure, give full play to the advantages of human resources, enhance the core competitiveness of enterprises, and change the traditional supply mode. In this context, human resource factors are becoming increasingly important, which is an important part of supply-side reform. Innovation, land, capital, and labor are the four major factors of supply-side reform. At the same time, it is necessary to clarify social labor relations and ensure that supply-side reforms can be synchronized with the current labor legislation based on its current content, so as to promote the development of our labor legal system. Meanwhile, it is necessary to balance the allocation of labor rights and responsibilities, accurately understand the content of labor law legislation, deepen public awareness of labor law, improve labor contract law, increase the flexibility of labor relations, strengthen regulations and autonomy, so as to protect the real interests of workers based on a sound legal security system. The following are suggested solutions to the existing problems in the context of supply-side reform based on the Labor Contract Law and related laws and regulations so that the labor legal system conforms to the development trend of the times.

\section{Opportunities for the construction of labor rule of law under the background of supply-side reform}

\subsection{Adjusting the allocation of rights and responsibilities for protecting workers}

In the context of supply-side reform, it is necessary to clarify the demand-supply relationship. In the process of promoting supply-side reform, the proportion of supply and demand for investment, consumption and export should be balanced. Our country hopes to rely on supplyside reform to optimize the development structure of Chinese enterprises and change the extensive development mode in the past.

In the trend of economic integration, if we still take price as our leverage, it is difficult to gain market share for a long time. Therefore, our country hopes to change the development structure, adjust the supply and demand relationship, and win the market by product quality. For example, our country adopts export tax rebates to promote the export of commodities, and promulgates relevant policies to improve product quality testing standards, improve product quality, attract consumers to pay attention to high-quality products, and stimulate consumption. In order to form a long-term and lasting economic development mechanism, we must pay attention to the role of human resources during the reform period, change the structure of human resources, and standardize the human resource market with policies and deal with past non-compliant behaviors.

In the context of supply-side reform, it is necessary to 
manage the factors of production. At the same time, the core structure should be adjusted from the aspects of resources, labor, technology, environmental resources, etc., to balance the factors of production in all aspects, and to enable benefits of all parties in society in a state of dynamic balance such as laborers, governments, and meet the actual needs of capital in pursuit of profits at a certain level, while solving the market lag problem. In the process of supply-side reform, it is necessary to follow the national modernization development goals and balance economic and ecological factors. Market resource allocation should also be adjusted to balance the principle of allocation, so that during the early game between the employer and the employee, the two parties will be in a state of dynamic balance.

Considering that China has not established a collective consultation system, in the game between employers and employees, workers are still a disadvantaged group. In order to avoid this unreasonable phenomenon to be existing for a long time, it is necessary to clearly specify rights and obligations of employees during the employers' recruitment and human resources management. In addition, during this period, the government will adopt policies to reduce the harm caused to workers by the reform, and stipulate through the policy the responsibilities of employers during the employment, adjust the allocation of rights and responsibilities to ensure the continued long-term development of the national economy.

\subsection{The labor law is consistent with the direction of supply-side reform}

The labor contract law and other relevant legal documents have the characteristics of conformity with the supply-side reform, so that workers' rights and interests can be protected through the construction of the labor legal system. At the same time, the allocation of rights and responsibilities in human resources can also be adjusted and the human resource allocation can be transformed to market allocation in line with the supply-side reform requirements.

However, most of the content of our labor contract law provides a wide range and are not practical, so in the formulation and application of it, some companies will exploit the loopholes of the law under the background of supply-side reforms due to its lack of practicality. At the current stage, it is also necessary to continuously introduce policies and regulations related to the labor contract law, standardize the human resource management of the employer, and carefully divide the rights of each party and strengthen the law based on the supply-side reform strategic requirements and the content of the "Labor Contract Law". Propaganda efforts should be made so that workers understand their own rights and interests and can protect their interests from harm with the help of "Labor Contract Law", so as to form a harmonious and stable labor relationship in the rapid economic development ${ }^{[1]}$.

For example, after the new economic normal, our country has been continuously improving the content of labor laws in combination with the content of supply-side reforms. Taking Guangdong Province as an example, through the statistics obtained by Guangdong International Law Firm on local labor cases in 2014 and 2015 , it can be found that the growth rate of labor disputes in Guangdong is flat. From the data, it can be found that Guangdong Province has kept improving the "Labor Contract Laws" and regulations, and solved the frequent problems of labor disputes in the past through the "Mediation and Arbitration Law". The employers adjusted the employment management content after the promulgation of the "Mediation and Arbitration Law" and the "Labor Contract Law" so the illegal employment events has reduced.

\subsection{Supply-side reform promotes the construction of labor law}

In the process of the rapid economic development in our country, it is necessary to change the supply relationship and stimulate market vitality. Several supply-side reforms have occurred since the early days of the founding of the People's Republic of China. In the early days of the founding of our country, during the socialist transformation, there were many problems in the transformation of private industry and commerce into state-owned enterprises. However, with the efforts of the government and the cooperation of the people, our private land was transformed into collective land in a short period of time and the nature of the land was changed. In the next stage of national planned economic period, serious corruption problems occurred. Due to lack of strong and scientific regulations, there were bureaucratic problems during the development in most state-owned enterprises, which reduced the work enthusiasm of the staff and made production inefficient. In the state of non-compliance in resource allocation, the market consumption showed an irregular development trend, resulting in a serious deviation of the supply relationship, which caused a great blow to our economy.

In 1993, our country re-clarified the goals of economic system reform and improved the content of the socialist market economy, which was an important measure to promote national economic development after reform and opening up. After the reform of the national economic system, in accordance with the content of the socialist market economic system, the "Labor Law" was promulgated in the second year, in which the labor relationship was determined, the allocation of labor rights and responsibilities was clarified. Labor resources were integrated through market allocation, and in the following years, it promoted the supply-side reform and development and achieved good results. Our economy developed towards marketization through large-scale reforms. However, during the construction of the market economy structure, there were many unsatisfactory aspects. For example, although the degree of marketization in China has become higher, the internal corruption problem was extremely serious. The stateowned assets were rapidly lost and most workers had been laid off without economic compensation, which has caused many serious social problems. 
In view of the problems that existed during the supplyside reform in the past, we must draw lessons and formulate measures to protect the basic rights of workers at the same time. To do this, we need to learn from the relevant experience of other countries during the economic system reform and build a sound labor legal system. In the history of the United States, large-scale supply-side reform activities broke out, which are also known as the Roosevelt New Deal. Excessive speculation in capitalism led to an economic crisis, but the Roosevelt New Deal protected the rights of workers through the social security system and gave poor members a certain amount of relief funds. A series of regulations were formulated, for example young children were not allowed to be employed, and the working hours were also regulated, so as to ensure the rights and interests of workers, which also promoted the employment of workers to a certain extent. It is undeniable that this supply-side reform in the United States has been very successful, and it is a case that we can learn from. China needs to learn from its advantages in economic reform. During the construction of the labor legal system, we must pay attention to the balance of rights and interests of grass-roots workers. During the period of social security rule of law, we need to promote economic development, solve the problems of difficult employment for the general public and irregular employment of enterprises through the construction of labor legal system.

\section{Challenges to the construction of labor law under the background of supply-side reform}

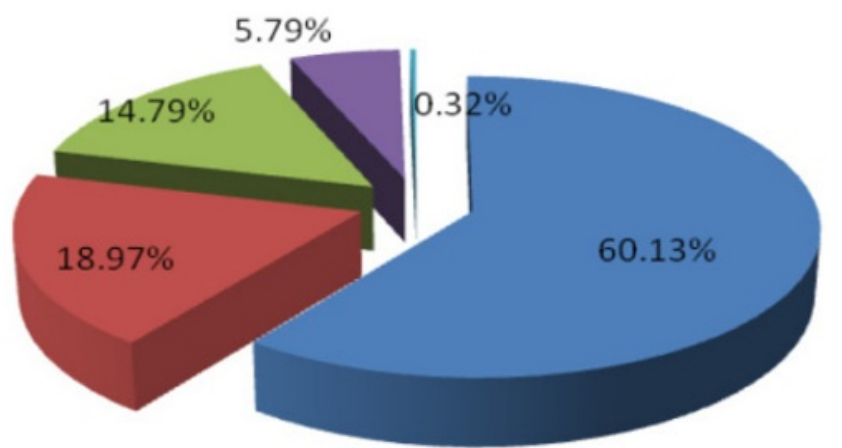

Verdicts

Conciliation

Withdrawal \& equivalent claims

Transfers and others

Prosecution rejections

The labor contract law is still in the process of improvement. During the implementation of the labor contract law, there are many controversies in the society. By analyzing the problems during the implementation of the labor contract law, we can find that there are deviations in the public perception of the labor contract law, which leads to impossibility to maintain stable labor relations and increases in the cost of labor in the employment. It is difficult for companies to have sufficient funds to run various projects, which will undoubtedly weaken the core competitiveness of the company. Since the labor contract law formulated by the country has many requirements on employment, and workers are overprotected, the protection rights and responsibilities shifted to the workers may cause the employer to lose its rights and interests due to dismissal during employment. In addition, the assignment of rights and responsibilities in the "Labor Contract Law" is too simple, and the responsibility for dismissal is attributed to the employer. Workers have absolute advantages over employers in dismissal. If the various contents of the Labor Contract Law cannot be improved and the rights of the employer and workers are not clearly defined, it is likely to cause small and mediumsized enterprises to lose a lot of funds due to employment problems, thus making it difficult for them to continue to develop. Figure 1 is the statistics of labor disputes from July 2018 to April 2019 in Jing'an District Court in China.

\subsection{Deviations in the perception of the "Labor}

Fig1. The statistics of labor disputes from July 2018 to April 2019 in Jing'an District Court in China

From July 2018 to April 2019, Jing'an Court received a total of 621 labor dispute cases and closed 622 cases, with a closing rate of $100.16 \%$ over the same period, maintaining a virtuous circle of case hearings. Figure 2 shows the types of labor dispute cases of Jing'an Court from 2018 to 2019. 

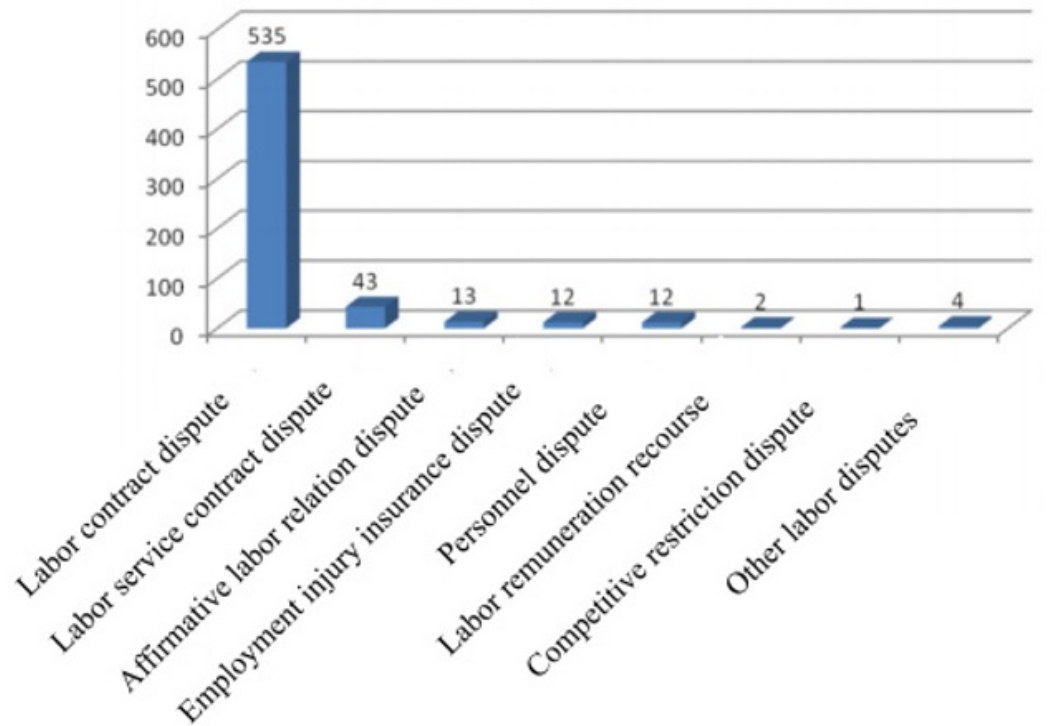

Fig2. types of labor dispute cases

In addition, the total withdrawal rate was $33.76 \% ; 2$ cases were dismissed, which accounted for $0.32 \%$; referrals and cases tried in parallel with other cases of this court totaled to 36 , accounting for $5.79 \%$. Figure 3 is the graph of data analysis of pre-arbitration labor dispute cases in Jing'an Court from 2018 to 2019.

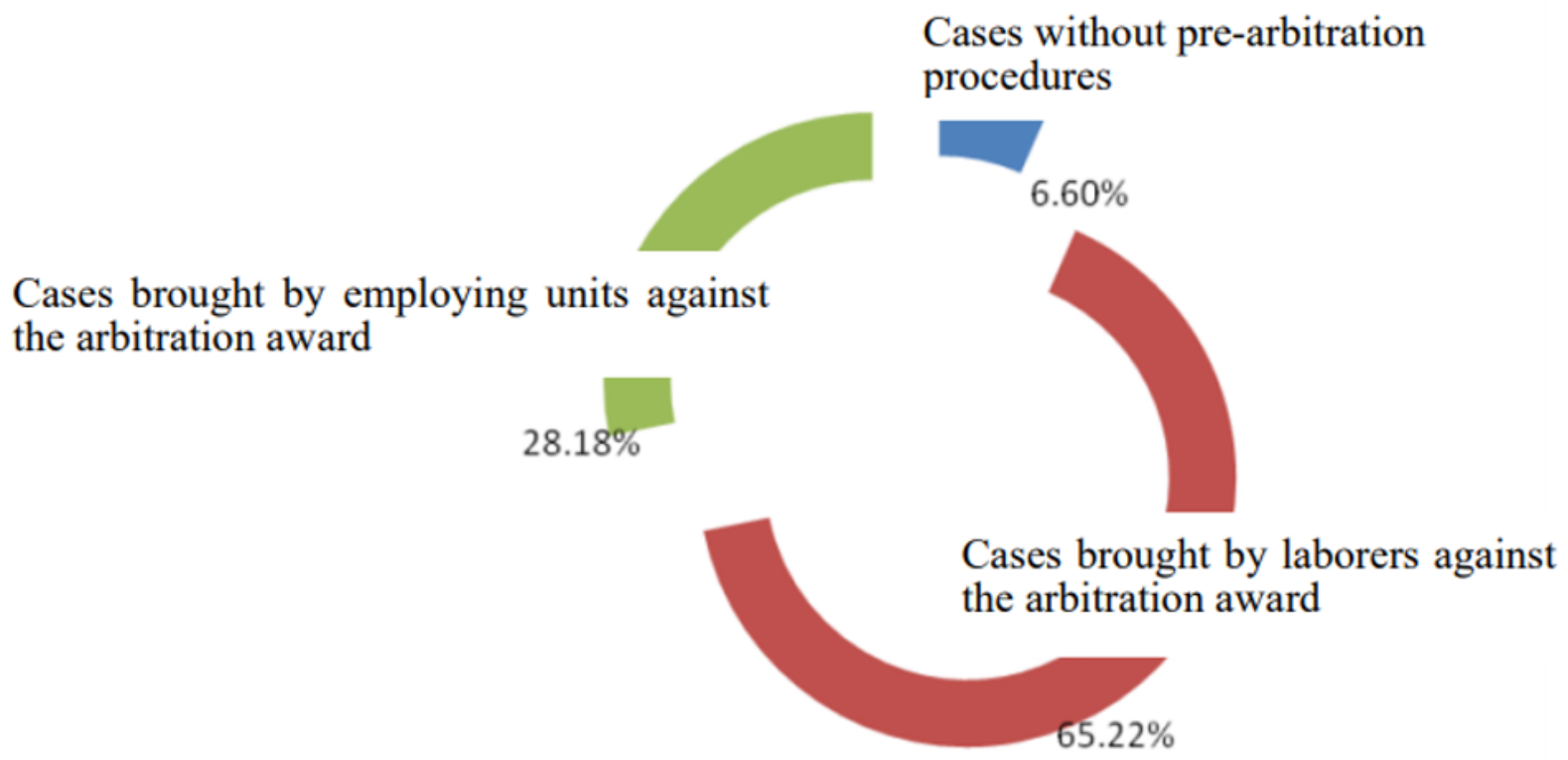

Fig3. graph of data analysis of pre-arbitration labor dispute cases

\subsection{Disturbed labor market environment}

In the context of market economy, labor relations need to be adjusted. At the same time, labor rights and responsibilities should be optimized to solve the contradiction between the stability and flexibility of labor relations. In the context of the supply side, the labor law system should be rationally applied to promote social and economic development. The institutional design needs to be practical. At the same time, during the design of the labor contract law, the employment period of labor force and the content of dismissal protection should be clarified, and all aspects should be balanced. The labor contract law will play its role when it's acceptable to both employers and laborers. Meanwhile, our labor contract law has no restrictions on the application of labor contracts. If the employer dismisses the employee personally within the contract period, he needs to pay for the employee's economic compensation. If it is not renewed after the expiry of the fixed period, no financial compensation needs to be paid. Under the "Labor Contract Law", some enterprises have adopted short-term contracts to circumvent the problem of compensation. The way of signing every year results in excessive labor relationship liquidity and puts workers at a disadvantage. In addition, in order to reduce the cost of employment, companies have not carried out various training activities in accordance with work requirements and the provisions of the Labor Contract Law, which has led to industrial upgrading being hindered. This will affect the quality of the company's products and is not in line with supply-side reform, which has a great negative impact on the development of the enterprise $^{[2]}$.

A law firm in China conducted data collection and research on labor disputes across the country, and found that China's labor contract disputes are problematic. In the past two years, statistics found on unsigned labor contract 
disputes were as many as 118,766 cases. The difference in wages between the employees who signed the labor contract and those who did not sign is nearly twice. Therefore, the laws and regulations on the conclusion and renewal of the contract in the Labor Contract Law of China need to be further improved to avoid such cases.

\section{Suggestions for developing the construction of the rule of labor}

\subsection{Improve the flexibility of labor relations}

In order to adapt to the diversity of social and economic activities, it is necessary to solve the problems of employment relations and increase the flexibility of labor relations. At the same time, the "Labor Contract Law" should be revised, and the labor contract period should be appropriately adjusted to solve the problem that employers use short-term contracts to avoid paying compensation to dismissed workers. Reasonable amendments to the labor contract period can also avoid the malpractice that the enterprises only employ laborers of the appropriate age. If a worker has worked in the same unit for more than 10 years, it is necessary for him to sign a labor contract with the employer for an indefinite period. It is stipulated in Article 14. At the same time, the employers should be prevented from guiding the workers to suspend work for any unjustified reason. The employers must implement the labor cooperation regulations and protect the rights and interests of workers. In addition, when a laborer signs a labor contract with an enterprise, it is necessary to clarify the premise. On the basis that both parties agree to renew the contract, the employer has the right to terminate the contract after it expires in accordance with the "Labor Contract Law". Furthermore, the employer cannot terminate the contract for any unjustified reason during the contract period, otherwise, it must pay a sufficient amount of compensation to the workers.

In order to avoid employers from evading economic compensation by signing short-term contracts, the content should be clarified in the "Labor Contract Law", the number of times the employers and employees sign contracts should be limited. If the employers and workers sign three times, it can be regarded as fixed-term labor contract, and the signing time needs to be extended.

\subsection{Expand the scope of labor relations autonomy}

In the context of supply-side reform, individual labor relations need to be transformed into collective labor relations, and the laws and regulations related to collective labor relations in China need to be improved. Taking into account the collective workers' rights and interests, in order to ensure that China can have stable and harmonious labor relations, the content of the "Labor Contract Law" should be revised. It is also necessary to establish a sound collective contract legislation, so that both employers and employees can play in an evenly matched state so as to protect the rights and interests of workers. At the same time, individual labor relationship rules in the "Labor Contract Law" should be amended. When the employer and the laborer sign a contract, they can adjust the employment relationship through supplementary terms and clarify the rights and interests enjoyed by both parties $^{[3]}$.

\subsection{Supplement and improve the employment security regulations}

In the context of supply-side reform, it is necessary to improve the content of the "Labor Contract Law", and at the same time, the focus of labor legislation should be changed to rationally allocate the rights and interests enjoyed by employers and laborers under the "Labor Contract Law". Efforts should be made to ensure that employers carry out various tasks in accordance with the requirements of labor legislation so as to protect the rights and interests of workers during work, and carry out knowledge cultivation and other activities for workers according to the requirements. The labor supply structure can be optimized by promoting the progress of capital management through human resource management. Meanwhile, it is necessary to improve the content of the "Employment Promotion Law", and strengthen the implementation according to it. Appropriate amendments should be made targeting its existing problems so as to eliminate employment discrimination in society and create a harmonious and stable labor relationship. In addition, the legislative work in the field of social security in our country should be improved to solve the drawbacks of lagging legislation. At the same time, insurance legislation should be gradually improved to protect the rights and interests of workers.

\section{Conclusion:}

In the process of supply-side reform, it is necessary to obtain the problems of labor relations and improve the laws and regulations of the "Labor Contract Law". The social security system should be perfected to standardize the content of employment laws, so as to create a harmonious and stable labor relationship, optimize labor relations rights and responsibilities, and enhance the flexibility of labor relations.

\section{References}

1. Zhu Meijuan. The Deficiency and Improvement of the Economic Compensation Clause of the "Labor Contract Law" [J]. Journal of Tianjin Sino-German University of Applied Sciences, 2019(06):119-122.

2. Meng Lan. Analysis of the Relationship Between Labor Law and Social Security Law in the New Period[J]. Legality Vision, 2019(24):79-80.

3. Dong Baohua. Concept Adjustment and System Update in the Revision of the Labor Contract Law [N]. Entrepreneurs' Daily, 2016-06-03(W03). 